\title{
Identity Crisis in Andrea Levy's Back to My Own Country - A View from West to East
}

\author{
V. Jayajothilakshmi, R. Kannan
}

\begin{abstract}
A man without identity is nothing in this world. Identity gives human a sense of belongingness. A person suppressed by others in the name of racial discrimination may feel inferior. This inferiority complex leads him to dig his history and know his originality. The people of the colonized land may undergo this kind of complexity. Their complexity makes them either to keep away from the society or hide their originality. A person feeling inferior may at a certain point protest and stabilizes his/her identity. Black writers from various colonized places express their emotions and feelings through various stories in writing.
\end{abstract}

Keywords: black, colonized, identity, inferior, originality, racial discrimination

\section{INTRODUCTION}

$\mathrm{M}$ any writers have used their pen to bring many changes in the society and some write just for entertainment. The stories or novels of a few writers touch the heart of the readers and make them to visualize everything by being one with the story. The works of the black writers are entirely different as the writers speak through their writings. They are not just words, but the feelings and emotions of the people in the colonized land. People being slaves in their own motherland are very pathetic and also sensitive. Such people sometimes protest and if they can't, then they become dumb and find no other way than to obey the orders of the oppressors.

\section{BLACK WRITERS AND THEIR THEME}

Change in life is unpredictable. We cannot say that human life will be alike forever till this world exists. The world we are living is the same but the people, their attitude, culture, civilization, thoughts, etc. changes from time to time. This change sometimes brings changes in the surrounding atmosphere where we live in. After that, the whole world seems to be different for them. No one can stand as master of others ever. Like a wheel, man's life has ups and downs. The man at the bottom may come to the top and the man at the top can come to the bottom at any time.

Likewise, the life of the African people has many obstacles, depressions, dominations, etc. Those people were let free some centuries ago; but they were controlled by the white people for many years. They suffered a lot because of slavery.

Revised Manuscript Received on December 20, 2019.

Ms.V.Jayajothilakahmi*, Department of English, Kalasalingam Academy of Research and Education, Krishnankovil, India. Email: jothi757@gmail.com

Dr.R.Kannan, Department of English, Kalasalingam Academy of Research and Education, Krishnankovil, India. Email: kannanraman1975@gamil.com
Auction was held. People were treated as animals. People became masters of people. The colour of the people spoke about their destiny. For a very long time, they were tortured. Was it their mistake to be born as black? That was their destiny. But that slavery and domination is now faded to some extent.

White people's suppression over the black people was blown into the air and the black people's life was set free. But whether they are enjoying and utilizing their freedom as black people is a big question. Literature mirrors the life of various people in various lands through the words of black writers. Kakali Bhattacharjee says, “... writers down the ages in all regions have taken up literature and its various forms to voice their thoughts and give their own colour to the various occurrences and happenings in this world [184]." In that way, the life of African people is also exposed by the writers of that land.

Recent Black writers deal with the same themes of the previous writers in some or other way. Modern writers, including women writers have the freedom to speak through their works. Sangeetha Verma says, "Much of the recent works/arts authored or created by women touches directly or indirectly on questions of personal and cultural memories [140]." The story or concept of their writings explains the identity crisis, loss of self, culture, colonialism, etc. This shows the present black people's life. Whether they are happy and satisfied with their tradition, culture, colour, race is also a question. The works of black writers such as AfroAmerican, Caribbean, African, etc. show something different from the writings of others. The main subjects of their writing are identity crisis, slavery, alienation, etc. In their works, we can see humors too. If we analyze it deeply, we can understand the humiliations of those people as they undergone.

\section{IDENTITY CRISIS IN ANDREA LEVY'S ESSAY}

Andrea Levy is a contemporary Black British writer. As a black writer, she could analyse the life and mentality of the black people and project it in her works. Her ancestors were the aboriginals of Jamaica and they belonged to the Caribbean island. Andrea Levy's parents moved to Britain and so she had chances to have new experiences with white people. In her works, she has explained the psyche of black people in white people's land. Her essay "Back to My Own Country (an essay)" gives the details about her own life as well as the development of her writing career. It shows 
how a black immigrant tends to be like white people and hates her own heritage. This paper shows the developmental phase of Levy's hatred for the black to her oneness with them.

The book Six Stories \& an Essay begins with an essay "Back to My Own Country" which is the autobiography of Andrea Levy. The writing career of the writers will begin with an incident that induces them to express their own experiences or others' experiences in their works. Andrea Levy is not an exceptional. The essay in the book shows Andrea's experience with the black and white people. Though the black people were away from slavery and trying to lead a new life, the thought in the white people's mind was same till a few decades back. Once, the slaves were worked in land, industry, army, house, etc. All these were picturised in the native writers' works to show their firmness in their culture. Parama Sarkar Says, “...writing produced by them was not only based on the unquestioned superiority of European languages and cultures, but also a calculated strategy to keep the native cultures firmly in their place."

\section{A. Experience with White People}

The domination and control of the white people and their ill-treatment became a scar in the heart and mind of the black people. Generation after generation has undergone this problem and hence it settles in the subconscious mind of the black people. Though years passed, situation changed, and lifestyle varied, the black people still have that scar in them. This makes them to keep themselves away from white people, and feel unsecured. At the same time, white people see the black as alien; because once they were the masters of them. This concept too buries inside the mind of the white people. That is the reason, why that clash between those two exists either consciously or unconsciously. Andrea Levy, the Black British writer exemplifies this black people's state through many incidents that took place in her life. She begins her essay "Back to My Own Country" with a small flashback. She shows the racial problem through an incident took place in a bus.

\section{B. Andrea's Parents as Immigrants}

A black man travelling in the bus tried to be jovial and friendly with the white people. But their response to him was very odd and arose question in the young mind of little Andrea. That man became an alien among others. Though the country has mixed culture, still there is a vast difference in their knowledge and understanding. As a child, Andrea did not know the cause of that insult, but later she realized it. She says, "After the end of slavery in the Caribbean the British continued to rule their islands through a policy of racial apartheid right up until they finally left in the nineteen sixties.... This is the absence, the gap in knowledge, theamnesia of the British that made the black man on the bus such an alien [14]."

Andrea's parents were educated and lived better life in Jamaica. In contrast, their life in London society made them to feel odd. The reason was that they were immigrants and outsiders in that land. This forced them to face many consequences. Education gained from Jamaica became invalid in London. Andrea's mother kept her self-respect by not borrowing money from others even in their poverty. Black people were poor. They were forced to accept whatever happened to them. People were judged on their colours. Only colour spoke about a person and not their characters. White people never mind it. Others have to note how black they are. Even black people didn't want to show their originality and felt ashamed of saying about their country.

\section{Racial Discrimination}

Racial discrimination was the main cause for all the problems. It was common that 'white' people hate 'black' people. What to say if black hate black? God created human beings equally. But humans created racism, divisions, classism, and so on. Racial discrimination made black people to hate their culture, lifestyle, colour, etc. They felt proud to join with white, lead life like them, play with them and follow their culture. The author says, "My mum once told me how, back in Jamaica, her father would not let her play with children who were darker than her.... We would always have lighter-skinned children to pay with [8]." Some hated themselves for being black. People began to live by keeping their life background as secret. They felt elevated being with 'white'. The hesitation in black people's mind induced them to hide their real identity and search for a new one.

Many people think that slavery was only been in America. They are unaware about many places which suffered under slaveries. Caribbean island is also an unknown place which occupies that category. Caribbean people belong to the black people community. They never felt proud for being in black community. Everyone tried and tries to improve their life and themselves to withstand in the society with respect. The contradictory ideas here are, some try to change their identity and some are firm in their original identity and protest against the world to strengthen it. A person, who realizes his/her ancestors' life and identity, can never neglect it for any case. Because, that is their originality and it says who they are. Whatever identity one creates will get the secondary place, as in the first place stands their family's identity.

\section{Andrea's Real Identity}

Once Andrea Levy too, felt awkward to stand near the black people. She did not like to reveal that she belonged to the Caribbean island, and not ready to accept that she belonged to dark family. A big turning came to her life when she visited her native land Jamaica. Until then she had more complications for being black. She was very conscious to be with white people, attain their manners, having them as playmates and so on. She never allowed her classmates to know her residing place. She had the mentality that white people are superior to any. Her Caribbean identity did not give her satisfaction; instead it made her to feel humiliated. The humiliation and colour of being dark made her to find identity among the white. So she kept herself in the company of the native people. 
Even her parents did the same that they never permitted her to mingle with the slave community. They knew their original identity. They tried to hide it from others and showed a way by being role model for their daughter to think, revealing her originality is like a sin. Eddie Hewitt says, "Levy is reflective and self-analytical in this essay and combines the personal with the universal. In telling us about her own story and the story of her family, she also relates to millions of other people and to their experiences of Britain and the Caribbean."

Andrea never visited her native for many years. Her visit to Jamaica rejuvenated her mind. Everything became upside down. Once she hated to be black and among black. Later she is happy to be Caribbean and Black British writer. For years she thought the white people's identity as a superior one. Her understanding made her to realize the truth buried in her native island. A complete change in her mind is clear in the way she accepted the reality. The truth she knew made her to take the identity in an optimistic way. Moreover, in Jamaica she came to know the history of her country and their past and present condition. She had the ability to compare them and came to a conclusion. The subconscious thoughts were provoked while hearing the history and her inner instinct was illuminated. Unlike others and old Andrea, she takes her identity as granted. She took that identity as a weapon to defeat humiliates. She says, "I am now happy to be called a black British writer, and the fiction I have written has all been about my Caribbean heritage in some way or other [12]." The chance given for her to write her deep feelings and the reality she understood from her motherland people made her to shine as a writer in this world.

\section{CONCLUSION}

Andrea tries to keep her own identity as well as Jamaicans'. In some way or other she touches the Caribbean heritage in her writings. There are many people trying to imitate others and forgetting their originality. The proverb "The grass is always greener on the other side" suits them. The way others behave, speak, and live, stimulate one to think that theirs are better way to live in this earth. The outward show creates a veil in the eyes of the onlookers and blocks them to see the inner reality. The outward look may deceit them. All the outward things in the world enter into human mind through eyes. Most probably brightness and beauty attract the eyes. This is why black becomes next to white. Apart from all these things, black shows the real stamina and it has its purity. Black people as working class were labeled not by nature but by human. Andrea Levy's identity moved from west to the east. She realized her true identity as Jamaican and not as western.

\section{REFERENCES}

1. Andrea Levy, Six Stories \& and Essay, UK: Tinder Press, 2014, pp.3-19.

2. Kakali Bhattacharjee, "The Existence of Border Lines as Never Before", in Dynamics of Diansporic Identity in Commonwealth Literature, Arvind M.Nawale and Nibedita Mukherjee. New Delhi: Authorspress, 2013,pp.184-185.

3. Parama Sarkar, Postcolonial Literatures, Hyderabad: Orient Blackswan Private Ltd, 2016.
4. Sangeetha Verma, "Constituting a Female Nature: A Therapeutic Strategy for Woman and Earth", in FROM BONDAGES TO EMANCIPATION Woman in English Literature, Dr.Sheeba Rakesh and Capt. Dr.Arvind M.Nawale. New Delhi: Authorspress, 2012,pp.139-142.

5. Eddie Hewitt, 2015, http://www.connected-cultures.com

\section{AUTHORS PROFILE}

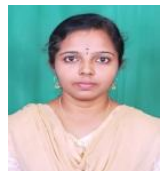

V.Jayajothilakshmi is working as the Head and Assistant Professor of English in Vyasa Arts and Science Women's College, Subramaniapuram. She has completed her M.A., B.Ed., M.Phil., M.Sc(Psy.)., and pursuing her Ph.D in part-time at Kalasalingam Academy of Research and Education under the guidance of Dr.R.Kannan. She is doing her research in Indian Writing in English. She has been working as Assistant Professor for seven years. Her teaching areas are Indian writing, British Poetry, Canadian Literature, American Literature and others at both under and postgraduate levels. She has presented a paper at a conference.

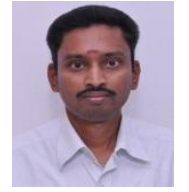

Dr.R.Kannan is an Associate Professor of English in Kalasalingam Academy of Research and Education. He pursued his Ph.D in 2009. He has been working as Associate Professor for fourteen years. Under his guidance, one pursued his Doctorate, fourteen scholars completed their M.Phil dissertation. At present, under his supervision, four scholars are pursuing their Ph.D. He has published two papers in Scopus Indexed Journal, fourteen papers in UGC listed and other journals and also presented papers in both National and International conferences. He was a Doctoral Committee Member in VIT, Vellore. He is the journal reviewer of Humanities, Online International Journal, Switzerland. He is the BEC Centre Exams Manager and Speaking Examiner for BEC in Kalasalingam Academy of Research and Education. 